\title{
MENINGKATKAN APRESIASI GENERASI MUDA TERHADAP PENYEDIAAN PANGAN MELALUI PAMERAN FOTO VISUALISASI BUDAYA PANGAN DI KOTA CIMAHI
}

\author{
Hermawan, W., Suryadi, D. dan Kuswaryan, S. \\ Fakultas MIPA Universitas Padjadjaran, Fakultas Peternakan Universitas Padjadjaran \\ E-mail: a359@unpad.ac.id
}

\begin{abstract}
ABSTRAK
Pangan adalah segala sesuatu yang berasal dari sumber hayati dan air, baik yang diolah maupun tidak diolah, diperuntukkan sebagai makanan atau minuman manusia (konsumsi) dan aktivitas budaya pangan bukan hanya sekedar penyajian untuk disantap/ kuliner, tapi suatu aktivitas panjang yang melibatkan sejumlah proses dan berbagai pihak.

Mengingat pangan merupakan bagian yang tidak terpisahkan dalam kehidupan sehari-hari, sejatinya pemertahanan ketersediaan pangan merupakan tanggung jawab seluruh lapisan masyarakat tetapi pada kenyataannya sektor agraris kurang diminati oleh masyarakat, terutama generasi muda. Salah satu cara pengenalan atau promosi atau edukasi budaya pangan adalah melalui pameran fotografi. Kegiatan pengabdian kepada masyarakat berupa "Pameran Foto Visualisasi Budaya Pangan Kota Cimahi yang berlangsung tanggal 13 Juni 2015 merupakan salah satu wujud upaya kepedulian yang bertujuan memperkenakan dan mempromosikan budaya pangan, khususnya di Jawa Barat, meningkatkan kesadaran masyarakat, khususmya generasi muda, terhadap pentingnya tanggung jawab bersama dalam pemertahanan pangan menuju ketahanan pangan nasional, di samping untukmempublikasikan hasilhasil penelitian dan pemikiran-pemikiran yang dihasilkan di dalam kampus.

Dengan melihat animo pengunjung dan dan umpan balik yang baik, maka kegiatan pameran serupa seharusnya menjadi kegiatan rutin. Melalui pameran foto wawasan tentang budaya pangan dapat mejangkau generasi muda khususnya dan masyarakat luas umumnya dengan fungsi-fungsi edukatif dan rekreatif.
\end{abstract}

Kata kunci: pangan, pemertahanan, generasi muda, edukasi, pameran

\footnotetext{
ABSTRACT

Food is everything that comes from biological sources and water, whether treated or untreated, applied as human's food or drink (for consumption) and cultural food activity is not just a culinary presentation or presentation to eat, but a long activity including some processes and different parties.

Considering that food is an inseparable part in daily life, the true preservation of food security is the responsibility of whole society, but in fact, the agrarian sector is less enthused for the society, especially the young generation. One of the food cultural education introduction or promotion is by photography. Community Service Activity in form of "Pameran Foto Visualisasi Budaya Pangan Kota Cimahi” held in Cimahi on 13th of June 2015 is one manifestation of the efforts aimed in introducing and promoting food culture, especially in West Java, increasing public awareness especially the young generation about the
}

importance of shared responsibility in the preservation of food towards national food security, in addition to publish the results of the research and ideas generated in campus.By looking at the good interest of visitors and the good feedback, so this similar exhibition activities should be a routine activity. By this insight photo exhibition about food culture we hope that we can reach young generation in particular and public society with educational and recreational functions.

Keywords: food-retention of young generation-educationexhibition.

\section{PENDAHULUAN}

Pangan adalah segala sesuatu yang berasal dari sumber hayati dan air, baik yang diolah maupun tidak diolah, diperuntukkan sebagai makanan atau minuman manusia (konsumsi). Produksi pangan adalah kegiatan atau proses menghasilkan, menyiapkan, mengolah, membuat, mengawetkan, mengemas kembali, dan atau mengubah bentuk pangan, dengan tujuan tersedianya pangan yang memenuhi persyaratan keamanan, mutu, dan gizi bagi kepentingan kesehatan manusia, terciptanya perdagangan pangan yang jujur dan bertanggungjawab, serta terwujudnya tingkat kecukupan pangan dengan harga yang wajar dan terjangkau sesuai dengan kebutuhan masyarakat.

Pembangunan bidang pangan diselenggarakan untuk memenuhi kebutuhan dasar manusia yang memberikan manfaat secara adil dan merata berdasarkan kemandirian dan tidak bertentangan dengan keyakinan masyarakat. Karena posisi pangan yang sangat strategis dalam pengelolaan negara, maka diperlukan sistem pangan, yaitu segala sesuatu yang berhubungan dengan pengaturan, pembinaan, danatau pengawasan terhadap kegiatan atau proses produksi pangan dan peredaran pangan sampaidengan siap dikonsumsi manusia.

Ancaman langsung terhadap produksi pangan dunia sudah terlihat jelas, dengan munculnya bencana kelaparan yang terjadi di berbagai negara, yang paling parah terjadi di berbagai negara Afrika. Secara umum ancaman terhadap produksi pangan nasional datang dari: pemanasan global (anomali iklim dan cuaca), alih fungsi lahan untuk kepentingan nonpertanian (industri, perumahan, dan lain-lain), hama penyakit tanaman, eksploitasi yang berlebihan terhadap sumberdaya pertanian tanpa mempertimbangkan kearifan lokal, nilai tukar produk pertanian yang makin menurun, insentif yang rendah dari aktivitas sektor pertanian, dan partisipasi yang makin menurun dari generasi muda untuk masuk ke sektor pertanian.

Kesadaran akan pentingnya keterjaminan ketersediaan pangan oleh semua pihak/stake holder untuk berpartisipasi dalam pembangunan pangan menjadi sangat penting untuk terus disosialisasikan kepada seluruh 
komponen masyarakat. Makin tingginya kesadaran dan partisipasi masyarakat dalam pembangunan akan mendorong terwujudnya kedaulatan pangan dengan lebih cepat.

Berbagai hasil penelitian menunjukkan bahwa aktivitas sektor pertanian memberikan insentif yang rendah/kurang menarik bagi pelakunya. Oleh karena itu, partsipasi generasi muda untuk masuk sektor pertanian terus menunjukkan penurunan. Saat ini, hampir tidak dapat ditemukan pemuda/pemudi berada di sawah sedang menjalankan kegiatan pengolahan lahan, aktivitas di sawah didominasi oleh orang tua/lanjut usia. Tentu saja dalam jangka panjang fenomena ini tidak menguntungkan bagi sistem penyediaan pangan. Keterlibatan generasi muda sangat dibutuhkan terkait dengan upaya-upaya peningkatan produktivitas yang harus terus didorong melalui penerapan inovasi.

Aktivitas budaya pangan bukan hanya sekedar penyajian untuk disantap/kuliner, tapi suatu aktivitas panjang yang melibatkan sejumlah proses dan berbagai pihak. pemertahanan ketersediaan pangan merupakan tanggung jawab seluruh lapisan masyarakat. Ironisnya, terjadi penururan kesadaran masyarakat, terutama kaum muda, terhadap hal tersebut. Hal ini dapat dilihat dari kurangnya interes mereka terhadap sektor agraria.Oleh Karena itu, diperlukan upaya pengenalan dan promosi yang realistik bahwa pangan merupakan bagian yang tidak terpisahkan dalam kehidupan sehari-hari. Salah satu cara pengenalan atau promosi atau edukasi budaya pangan adalah melalui pameran fotografi.

Fotografi adalah sebuah bahasa visual yang didalamnya objek dikomunikasikan. Pameran adalah bentuk penyuluhan, yaitu komunikasi pesan yang disampaikan melalui visualisasi objek. Dengan demikian, pameran foto diasumsikan sebagai upaya mengenalkan, menyajikan kembali dan mempersusai khalayak (dalam hal ini pelajar) untuk mengetahui dan menumbuhkan ketertarikan terhadap bidang pangan yang dikomunikasikan melalui fotografi.

\section{METODE}

Sebagaimana tujuan penyelenggaraan pameran ini ditujukan untuk mengkomunikasikan tema-tema budaya pangan dan isu-isu terkait. Oleh karena itu, pameran ini hanya merupakan media penyampaian pesan, bukan menampilkan objek foto pertanian sebagai sebuah karya seni. Format pameran ini, seperti diisyaratkan oleh tajuknya, adalah penggunaan medium sederhana (foto) dalam upaya pengenalan kembali budaya pangan kepada generasi muda, agar kearifan lokal budaya pangan tidak hilang.

Kegiatan inventarisasi dan pendokumentasian objek pada proses pengumpulan objek foto bersadarkan tematik hasil dari FGD, pada tahap awalnya harus dilakukan proses penyadapan. Penyadapan tersebut bertujuan dalam rangka upaya memahami, mendalami dan menghayati materi objek berupa upaya memahami material kebudayaan pangan Jawa Barat yang menjadi tema dalam pameran foto tersebut. Wujud dari penyandapan ini, melalui teknik wawancara dan observasi lapangan.

Kegiatan FGD pada event pameran foto visualisasi budaya pangan Jawa Barat 2015, disesuaikan konsep dan tema, yaitu kekuatan foto lebih pada human interest sehingga tidak lagi di lingkup gaya documentary photography. Yang menjadi tema dalam kegiatan pameran foto budaya pangan kali ini terdiri dari: pertanian (huma dan sawah), peternakan, perikanan, pangan alternatif, alih fungsi lahan, dan workshop bab Wawadahan Banda Hajat serta Kaulinan Urang Lembur.

Dalam perspektif ilmu informasi, kegiatan inventarisasi objek informasi dilakukan melalui tahapantahapan collecting, processing, dissemination dan pada akhirnya preservation.

\section{TUJUAN KEGIATAN}

Tujuan Pelaksanaan kegiatan Pameran Foto Visualisasi Budaya Pangan Jawa Barat 2015 adalah upaya pengenalan dan promosi yang realistik dalam meningkatkan kesadaran masyarakat, khususnya generasi muda/pelajar terhadap pentingnya tanggung jawab bersama dalam pemertahanan pangan sebagai bagian yang tidak terpisahkan dalam kehidupan seharihari. Aktivitas budaya pangan bukan hanya sekedar penyajian untuk disantap/kuliner, tapi suatu proses panjang yang melibatkan berbagai aktivitas dan berbagai pihak. Kegiatan ini sebagai bentuk tindak lanjut atas hipotesis bahwa apresiasi generasi muda kita terhadap dunia pertanian mengalami pelemahan.Dalam kerangka pikir berbangsa dan bernegara, hal tersebut merupakan sebuah ancaman dikemudian hari.Kasus ini harus segera ditindaklanjuti dengan wujud nyata dan bukan sekedar retorika. Pameran foto tentu saja bukan sebuah solusi, tetapi diharapkan dapat memberikan efek persuasif.

\section{MANFAAT KEGIATAN}

Dilaksanakannya kegiatan Pameran Visual Foto Budaya Pangan Jawa Barat 2015 diharapkan dapat :

a. dapat menarik dan meningkatkan angka partisipasi masyarakat khususnya generasi muda untuk terlibat dan bertanggungjawab dalam pertahanan pangan.

b. sebagai sarana belajar bagi masyarakat/generasi muda, bagaimana proses pengadaan pangan berlangsung.

c. upaya mendokumentasikan berbagai teknologi dan kearifan lokal budaya pangan Jawa Barat.

d. dapat merangsang lahirnya inovasi di bidang pangan untuk memperkuat kedaulatan pangan.

\section{SUMBER INSPIRASI}

Dalam pendokumentasian dibuatkan pula database foto dengan segala yang hal yang menyangkut identitas foto tersebut. Hal tersebut dibuat sebagai acuan buku induk foto, dengan demikian jumlah, jenis, kekurangan, isi/deskripsi, matrik fotografi dan lain lain, dapat dengan mudah diketahui dan seluruh tim bisa mudah dan cepat mengakses. Sementara dalam ilmu dokumentasi budaya, bahwa infomasi tidak cukup berhenti di tahapan preservation dan pengarsipan, seperti halnya pada tahap sebelumnya yakni; collecting, processing, dissemination, dan pada akhirnya preservation. Dalam dokumentasi budaya 
yang menjadi fokus kajiannya adalah bagaimana dissemination, terutama pada wilayah how to deliverynya. Sehingga media pameran termasuk salah satu bagaimana informasi ini bisa menjadi bahan belajar bagi masyarakat luas. Oleh karena itu, informasi yang dihasilkan dari kajian ilmiah utamanya, diupayakan bisa terjangkau oleh masyarakat secara umum.

Produksi pangan adalah kegiatan atau proses menghasilkan, menyiapkan, mengolah, membuat, mengawetkan, mengemas kembali, dan atau mengubah bentuk pangan, dengan tujuan tersedianya pangan yang memenuhi persyaratan keamanan, mutu, dan gizi bagi kepentingan kesehatan manusia, terciptanya perdanganan pangan yang jujur dan bertanggung jawab dan terwujudnya tingkat kecukupan pangan dengan harga yang wajar dan terjangkau sesuai dengan kebutuhan masyarakat.

Aktivitas budaya pangan bukan hanya sekedar penyajian untuk disantap/kuliner, tapi suatu aktivitas panjang yang melibatkan sejumlah proses dan berbagai pihak. pemertahanan ketersediaan pangan merupakan tanggung jawab seluruh lapisan masyarakat. Ironisnya, terjadi penururan kesadaran masyarakat, terutama kaum muda, terhadap hal tersebut. Hal ini dapat dilihat dari kurangnya interes mereka terhadap sektor agraris. Oleh karena itu, diperlukan upaya pengenalan dan promosi yang realistik bahwa pangan merupakan bagian yang tidak terpisahkan dalam kehidupan sehari-hari. Salah satu cara pengenalan atau promosi atau edukasi budaya pangan adalah melalui pameran fotografi.

Dewasa ini sektor pertanian mulai ditinggalkan oleh generasi muda, karena dianggap hanya memberikan insentif rendah dan tidaklah prestisius sehingga kurang menarik bagi para pelakunya. Oleh karena itu Maka wajar saja angka partisipasi generasi muda semakin hari semakin menurun dan semakin memprihatinkan saja.

Atas dasar kesadaran terhadap pentingnya pemertahanan ketersediaan pangan ini, maka partisipasi semua pihak/stake holder dalam pembangunan pangan menjadi sangat penting. Hasil-hasil penelitian dalam segala aspek yang berkenaan dengan hal tersebut, seharusnya disosialisasikan kepada seluruh komponen masyarakat, untuk menumbuhkan rasa cinta dan tanggung jawab masyarakat, atau minimal memberikan pengenalan dan edukasi tentang proses-proses penyediaan, pengolahan, dan pemertahanan pangan nasional.

Keterlibatan generasi muda sangat dibutuhkan dalam upaya-upaya peningkatan produktivitas yang harus terus didorong melalui penerapan inovasi. Makin tingginya kesadaran dan angka partisipasi masyarakat dalam pembangunan pangan menjadi syarat terwujudnya kedaulatan pangan dapat lebih cepat terwujud dan isu-isu inilah yang menjadi fokus kajian kami. Perbincangan-perbincangan berkaitan dengan isu-siu tersebut diwujudkan dalam kegiatan PKM melalui pameran foto, dengan harapan sajian pada pameran foto kali ini, baik koleksi maupun cara menyajikannya (display)dengan baik, sehingga tujuan informasi yang hendak disampaikan yaitu dalam rangka memberikan edukasi budaya pangan kepada masyarakat khususnya generasi muda bisa tercapai.

Diskusi baik formal maupun informal berkaitan dengan isu-isu tersebut senantiasa terus lakukan sebagai upaya menemukan titik terang. Disamping terus-menerus dikumpulkan berbagai informasi serta data yang diperlukan. Pameran foto visualisasi budaya pangan Jawa Barat sesungguhnya telah dilakukan sebelumnya yaitu sekitar bulan April 2014 lalu di Pendopo Kabupaten Tasikmalaya, kemudian di Aula Sanusi Hardjadinata. Saran, kritik, serta harapan pengunjung terhadap isu-isu hangat mengenai kebudayaan pangan baik secara aktif (dialog) maupun pasif (ditulis melalui buku saran dan kritik) dihimpun untuk penyelenggaraan pameran berikutnya. Pada hari Jumat tanggal 17 April 2015 dilaksanakan di FGD yang menghasilkan beberapa bahasan:

\section{a. Tema Pameran}

Tema pameran yang diangkat masih sama dengan tema tahun sebelumnya, yang terdiri dari enam tema pokok; budaya huma/ladang, budaya sawah, budaya perikanan, budaya peternakan, pangan alternatif dan alih fungsi lahan. Pada pameran kali ini dipilih foto yang bisa mewakili tema dan artikel estetiknya. Pada tahun 2015 ini, kami juga menginventarisasi beberapa masalah sebagai berikut:

1. Mencari objek atau sumber foto yang akan digunakan. Hal ini perlu dipertimbangkan, karena tempat luas stand pameran yang sangat terbatas dan calon pengunjung yang heterogen, masal, dan tidak pasti (karena calon pengunjung pada panitia HUT Kota Cimahi dikondisikan oleh panitia). Sehingga foto yang disiapkan harus memiliki kualitas baik dari tema maupun estetika fotografi, maka di pameran kali ini, kekuatan foto lebih pada human interest tidak lagi di documentary photography.

2. Sarana dan prasarana pendukung. Strategi komunikasi grafis mutlak harus dilakukan sehingga sarana dan prasarana pendukung harus diupayakan optimum. Apalagi yang menjadi target sasarannya adalah generasi muda. Maka dalam pameran kali ini, komposisi display dengan sarana pengganggu indera harus seimbang. Strategi adalah, adanya workshop yang konsepnya berbeda dengan yang sebelumnya. Di Cimahi ini, workshop lebih ditonjolkan sehingga di pront stage stand, digelar kegiatan workshop dengan dekorasi yang diupayakan harus bisa menarik indera tidak hanya potensial users melainkan juga akctual users-nya. Di antara materi workshop yang dipilih adalah; wawadahan, kaulinan urang lembur (permainan); meliputi kaulinan lading yaitu ulin kenyed, dan kaulinan barudak sapopoe yaitu tak-takan.

3. Alat-alat dokumentasi. Melajutkan membangun sistem database foto, sistem pendokumentasian foto, pendeskripsian objek foto individual dan tematik, yang dilakukan kerjasama dengan kelompok mahasiswa Dokumentasi Budaya (setingkat UKM Universitas).

4. Tujuan Pelaksanaan, seperti di kegiatan pada tahun 2014 yang lalu, bahwa tujuan pelaksanaan kegiatan "Pameran Foto Visualisasi Budaya Pangan Jawa Barat" ini adalah sama yakni sebagai tindak lanjut hipotesis awal tentang lemahnya apresiasi generasi muda terhadap dunia pertanian. Dalam kehidupan berbangsa 
dan bernegara, hal tersebut menjadi sebuah ancaman disintegrasi bangsa di kemudian hari. Jika semua pihak dari elemen bangsa tidak ikut campur tangan. Oleh karena itu, perlu tindakan nyata dan bukan sekedar retorika sebagaimana pepatah, orang Sunda "kudu nyotoan sangkan jadi picontoeun lain pieunteungeun”. Makna ujaran ini sangat mendalam yaitu hidup baik sebagai individu, kelompok, maupun lembaga dan harus bisa menjadi suri tauladan di lingkungan masyarakatnya.

Pameran foto salah satu bentuk edukasi dalam rangka meningkatkan kesadaran masyarakat, khususnya generasi muda/pelajar terhadap pentingnya tanggung jawab bersama untuk penyediaan pangan, diperlukan sebagai upaya pengenalan dan promosi yang realistik bahwa pangan merupakan bagian yang tidak terpisahkan dalam kehidupan sehari-hari. Aktivitas budaya pangan bukan hanya sekedar penyajian untuk disantap/kuliner, tapi suatu aktivitas panjang yang melibatkan berbagai proses dan berbagai pihak. Kegiatan ini merupakan wujud dari bagaimana mempersuasi, yakni semua unsur masyarakat, untuk saling mengingatkan apa yang menjadi kewajiban azasi kita sebagai warga negara, tidak hanya menuntut hak azasi kita kepada negara.

Di sisi lain, apa yang disebut imperialisme budaya yang menjadi isu besar di dalam kancah perpolitikan internasional dewasa ini, seperti yang dilakukan Korea juga negara-negara lainnya dalam bentuk "Serangan Budaya" dengan senjata fashion, film, fun, dan lain-lain yang berujung pada "imperialisme kebudayaan". Jadi, secara tak sadar kita telah masuk pada episode perang dunia ketiga yaitu perang budaya. Menurut Imam Ali Khamerani (2005): Perang kebudayaan adalah saat suatu kekuatan politik atau ekonomi melakukan penyerangan atau teror halus terhadap prinsip-prinsip dan unsur-unsur kebudayaan umat lain.

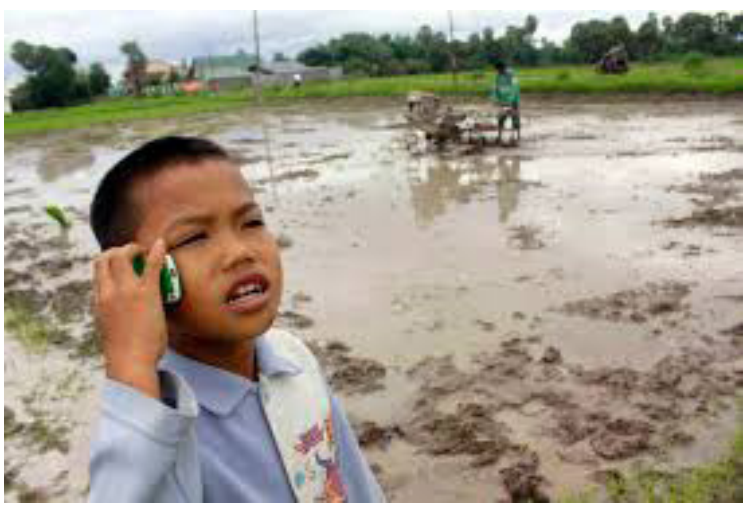

Gambar 1. Perubahan Sosial Masyarakat

Di sinilah kedudukan diadakannya kegiatan pameran foto visualisasi budaya pangan Jawa Barat jilid II, paling tidak dengan gencarnya arus informasi yang diterpa dari luar negara kita, anak-anak bangsa ini mendapat juga informasi yang seimbang dari dalam lingkungan bangsa dan negaranya, sebagai alternatif informasi supaya generasi kita tidak terfokus dengan arus informasi yang searah saja.

Berdasarkan teori komunikasi grafis bahwa indera harus distimuli oleh sesuatu yang tidak dianggap lazim, sesuatu yang mengakibatkan perhatian terganggu, sesuatu yang menyebabkan mata ingin memperhatikan (attention) yang kemudian akan menimbulkan interest, mengenal bahwa sektor pertanian dan kebudayaan pangan dianggap tidak menarik bagi generasi muda sekarang.

Perlu disadari bahwa pangan merupakan bagian yang tidak terpisahkan dari kehidupan sehari-hari tak terkecuali bagi kawula mudanya. Negara Indonesia yang terdiri dari pulau-pulau, berdasarkan perspektif pertahanan, tipe geografis yang seperti ini, tidakan preventif pertahanannya supaya terhindar dari ancaman negara asing, satu-satunya cara adalah pertahanan semesta, yang unsur kekuatan utamannya adalah dimilikinya kedaulatan pangan dan ketahanan pangan serta disiapkannya generasi muda terhadap kesadaran berbangsa dan bernegara.

Dalam rangka menumbuhkan kesadaran tersebut, diperlukan perspektif yang sesuai dengan jiwa zaman (zeitgeist). Pesatnya teknologi komunikasi menuntun generasi muda untuk melek teknologi informasi. Salah satu feature teknologi informasia adalah dokumentasi melalu fasilitas gadget. Nyaris tak ada aktivitas yang tidak mereka dokumentasikan.

dikaitkan dengan isu yang sedang tidak popular, misalnya masalah pangan diperlukan kecermatan dalam melakukan analisis wacana, sehingga akan diketahui bagaimana cara menarik interes sasaran. Distribusi informasi melalui pameran foto perlu dikemas sedemikian rupa agar memberikan feedback atau umpan balik yang positif. kendala lain yang dihadapi, terbatasnya pembendaharaan foto agar bisa dikemas berdasarkan standar hukum-hukum fotografi tetapi mudah diakrabi oleh sasaran. Oleh karena itu, pameran tersebut harus dikemas dengan cantik dan familiar. Hal itu disebabkan oleh pertimbangan utama, yaitu isu yang diangkat sudah bermasalah (isu pertanian tidak menarik perhatian target khalayak kami). Maka pameran ini harus harus didukung oleh acara yang kiranya dapat menarik perhatian khalayak, yaitu diadakan Workshop, pola interaktif, pemandu, permainan, informasi yang singkat, padat, dan jelas serta menarik.

Pameran (komunikasi visual) menurut Effendy (1992) dalam Teori Dinamika Komunikasi merupakan strategi atau ajakan. Agar komunikasi persuasif berjalan efektif harus dipenuhi tahapan formula AIDDA; Attention (perhatian) bagaimana merebut perhatian khalayak sasaran, Interest (minat) bagaimana menumbuhkan minat khalayak terhadap isu yang suguhkan, Desier (hasrat) bagaimana menumbuhkan hasrat khalayak sehingga sampai pada tahap memutuskan, Decesion (keputusan) bagaimana keputusan tersebut ditindaklanjuti dengan sebuah aksi, Action (kegiatan/aksi) bagaimana khalayak sasaran bisa dengan kesadarannya merespon dengan pola tindaknya.

Oleh karena objek yang ditampilkan berupa fotofoto hasil kegiatan dan bukan foto artistik, maka terdapat kekurangan-kekurangan secara kualitas visual (dalam hukum segitiga fotografi). Secara teknis dalam hukum segi tiga fotografi, setiap foto yang baik memenuhi standar fotografi yaitu komposisi shutter speed, diafragma dan ISO/ASA dengan komposisi bahasa dan latar fotografi. Pameran ini tidak ditujukan untuk menampilkan foto sebagai objek seni, melainkan komunikasi konten fotografi atau objek fotografinya. Oleh karena itu, 
diperlukan deskripsi dari setiap tema atau objek.

Adapun foto yang dipamerkan adalah hasil dari inventarisasi dan pengumpulan dari rekan, kolega di lingkungan Unpad sejak Juli tahun 2014 yang lalu hingga bulan Mei 2015. Foto-foto yang terkumpul disusun secara tematis yang dibagi ke dalam beberapa tema yaitu: 1) pertanian meliputi :

a. budaya huma/ladang

Mulai dari Babad Alas/Nyacar, Meupeuran, Ngadurukan, Ngaseuk, Nganaktu, Ngoyos, Tunggu, Panen, Ngakut Pare ka lembur, dll.

b. budaya sawah

Penyediaan pangan pokok beras, contoh budidaya sawah mulai dari; Babad Galeng, Mopok Galeng, Nyingkal, Ngagaru, Garit, Pabinihan, Tebar, Tandur, Ngarambet, Pare lilir, Reuneuh, Cul-cel, Rampak Hejo, Rampak Koneng, Panen, Moe Pare, Napian Gabah, Nutu nepi ka napi, Ngisikan, Ngagigihan, Ngakeul sampai siap santap, Artefak, dan lain lain,

c. Lalab,sayur-mayur, dan buah-buahan,

2) budaya perikanan : perikanan laut, perikanan darat meliputi kolam tradisional, kolam apung, budi daya ikan, dan lain lain,

3) budaya peternakan: peternakan tradisional, peternakan modern, pengolahan hasil peternakan dan lain lain,

4) pangan alternatif :jenis-jenis pangan alternatif pokok hingga pangan alternatif kontemporer,

5) alih fungsi lahan. Fenomena Lapar Lahan (Pemukiman, Jalan, Industri, Infra Struktur lainnya), maka terjadi Alih Fungsi Lahan yang sangat agresif. Lahan Subur termasuk Sawah,Kebun dan Hutan yang disulap menjadi lahan industri, dan lain lain,

6) Wawadahan Banda Hajat dan Kaulinan Huma dan Sawah, inilah koleksi tambahan dalam pameran kali ini, karena dari hasil FGD, material ini bias menjadi salah satu kekuatan merebut pengunjung untuk mau berkunjung ke stand pameran foto budaya pangan. Wawadahan ini diantaranya; ragam wawadahan dalam tradisi hajatan Urang Sunda masa lalu. Dan kaluinan huma dan sawah diantaranya, tradisi ulin kenyed, ulin angina, ulin cai.

\section{b. Media}

Seluruh objek adalah potret hasil fotografi dengan media yang sama seperti tahun sebelumnya. Ukuran Poster atau $20 \mathrm{R}$ atau $60 \mathrm{~cm}$ x $42 \mathrm{~cm}$ dan dicetak di atas kertas foto. Seluruh objek dikemas dalam frame kayu dengan alas kayu lapis dan ditempatkan dalam display berupa Ancak kayu berukuran $170 \mathrm{~cm}$ x $200 \mathrm{~cm}$. Pada ancak kayu dibentangkan kain Blacu untuk menempatkan foto-foto yang sudah dibingai. Setiap ancak kayu

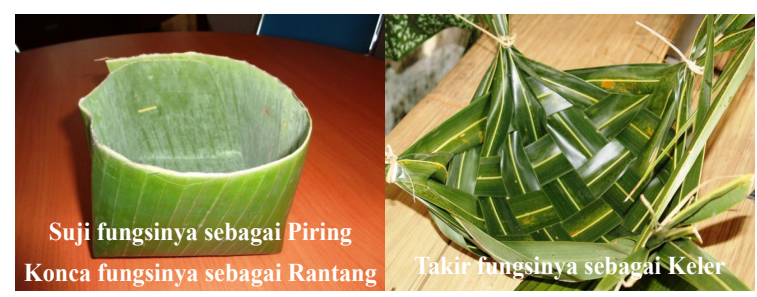

Gambar 2. Ragam Wawadahan Banda Hajat dimanfaatkan kedua sisinya, setiap muka ancak berisi 4 sampai dengan lima foto yang disesuaikan dengan kebutuhan tema.

\section{c. Sarana Penunjang}

Pameran foto biasanya memiliki kecenderungan statis, formal dan elegan. Berdasarkan sasaran khalayak utama yaitu pelajar SD, SMP, SMA/ remaja muda, perlu pertimbangan agar kegiatan ini memiliki daya tarik bagi mereka sehubungan dengan isu budaya pangan yang dianggap tidak populer dan media yang cenderung tidak lagi familiar serta lokasi pameran yang tidak akrab dengan khalayak maka pada pameran ini diusahakan agar setiap objek akrab atau tidak memiliki jarak psikologi. Atas alasan tersebut dalam kegiatan ini diperlukan sarana-saran penunjang berupa stimuli fisik, verbal dan vokal (Miller, 1972) agar tindak komunikasi dapat tercapai. Adapun aspek-aspek tadi mewujud meliputi:

1) deskripsi yaitu deskripsi setiap tema kelompok dan objek individual foto

2) artefak penunjangadalah objek nyata atau benda yang didokumentasikan

3) pemandu foto yaitu personal yang bertanggung jawab menerangkan tema dan makna dari masing-masing objek

4) permainan berupa kegiatan berupa kuis interaktif evaluatif.

5) workshop dan peragaan

\section{KARYA UTAMA}

Pelaksanaan "Pameran Foto Visualisasi Budaya Pangan Jawa Barat" ini diselenggarakan di lapangan Krida Kota Cimahi pada tanggal 13 Juni 2015 pelaksanaannya disaturagakan dengan kegiatan hari ulang tahun Kota Cimahi ke-14.

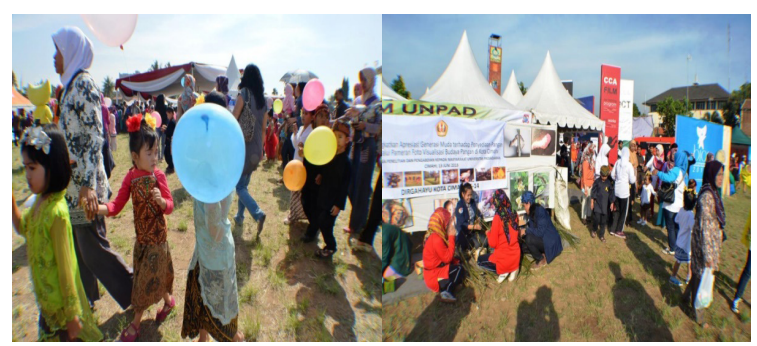

Gambar 3. Suasana lapangan Krida Kota Cimahi

Pengunjung yang hadir di lapangan Krida merupakan peserta gerak jalan terdiri dari berbagai unsur pemerintahan, TNI, Polri, Sekolah, LSM dan masyarakat umum

Untuk kegiatan pameran tersebut, tim sejak hari Kamis tanggal 13 Mei 2015 sampai hari Senin 8 Juni 2015, melakukan pengecekan mulai dari penyeleksian foto dan dari koleksi foto yang dimiliki LPPM terpilih 150 foto, pengepakan foto, termasuk mempersiapkan kendaraan untuk mengangkut koleksi tersebut. Mahasiswa dari Kelompok Mahsiswa Dokumentasi Budaya (setingkat UKM Universitas) dan mahasiswa mata kuliah Dokumentasi Budaya dari Departemen Ilmu Informasi dan Perpustakaan Fikom Unpad, membantu tim PKM melakukan pengemasan dan mempersiapkan tempat kegiatan. Para mahasiswa membantu pula dalam menyiapkan stand tambahan dan kebutuhan-kebutuhan 
lainnya yang bersifat fisik, seperti membuat sarana kaulinan urang lembur, dan lain-lain.

Yang menjadi kendala utama dalam mempersiapkan pameran foto kali ini adalah memilih foto, karena pameran diselenggrarakan di outdoor,tidak tersedianya lampu penerangan, dan juga faktor udara, debu dan embun yang dikhawatirkan merusak koleksi, sehingga tim harus bekerja super hati-hati. Penataan panggung pun menjadi kendala karena stand pameran sempit dan lokasinya dekat dengan panggung utama dan panggung tamu kehormatan, sehingga segi estetik harus diperhatikan. Selain itu, terjadi kesalahan pengepakan foto-foto yang sudah diklasifikasi, sehingga hal tersebut berakibat pada bertambahnya waktu pemasangan.

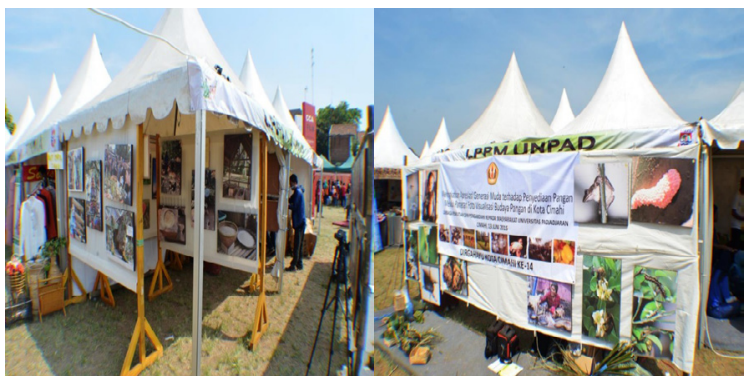

Gambar 4. Suasana Menjelang Pembukaan acara

Tepat pukul 09.30 WIB acara pameran dibuka langsung oleh Wali Kota Cimahi yang dipandu oleh Mc. Kang Uci dan Kang Saep (tokoh dalam 'preman pensiun').Jadi pada acara kali ini, tidak ada acara pembukaan yang dilakkan oleh LPPM Unpad. Pagi hari ketua tim dan seluruh tim sudah tiba di lokasi pameran. Sebelum acara resmi dibuka, ternyata pengunjung sudah berdatangan ke stand LPPM, mereka langsung mendatangi para mahasiswa yang sambil menunggu membuat konca dan pontrang ini dan sekaligus belajar dan berlatih membuatnya. Stand LPPM terus didatangi pengunjung dari mulai anak-anak, remaja, dewasa, dan orang tua. Suasana terbangun begitu akrab bernuansa budaya Parahiangan, antara lain Ibu Walikota menggunakan bahasa Sunda dalam pidatonya dan para muspida serta tamu undangan lainnya disuguhi pertunjukan wayang Cepot Bodoran pada saat peresmian acara.

Pengunjung pameran yang datang pada hari pertama berjumlah sekitar 5000-an orang, Di pagi hari pengunjung yang datang ke stand LPPM Unpad umumnya siswa-siswi Paud, TK, SD dan perwakilan dari kelembagaan Pemda dan TNI, dan sebagian masyarakat umum. Di siang hari, didominasi perwakilan darmawanita dari ibu-ibu persit (TNI) dan ibu-ibu bhayangkari (POLRI). Kemudian di sore hari mereka yang berkunjung ke stand LPPM Unpad didominasi oleh anak-anak, Siswa-Siswi SMP dan SMU dan peserta pameran yang kebetulan mengikuti kegiatan tersebut, diantaranya dari BJB, kantor Perustakaan dan Arsip Pemkot Cimahi, dan lain lain.

Meskipun kami belum pernah melaksanakan pameran semacam ini sebelumnya, akan tetapi acara berlangsung dengan lancar dan dinamis. Dinamika ini terjadi antara lain karena seting acara yang berlangsung memungkinkan terjadinya komunikasi dan keterlibatan pengunjung. Adapun skenario yang disusun oleh panitia internal masih seperti pola sebelumnya yaitu meliputi: panduan foto dengan pola interaktif, workshop/praktik membuat wadah dari foto yang dipamerkan, permainanpermainan, penyampaian informasi yang singkatpadat-jelas dan menarik. Pemandu pameran bertugas menjelaskan dan menerangkan setiap objek dan dalam perjalananan melihat foto, pengunjung diberikan kesempatan tanya jawab (pola interaktif). Bobot workshop dalam kegiatan pameran ini memiliki bobot yang sama dengan bobot pameran fotonya. Lokasi workshop ditempatkan di front stage (di bagian depan stand). Prinsipnya, selain melihat foto pengunjung

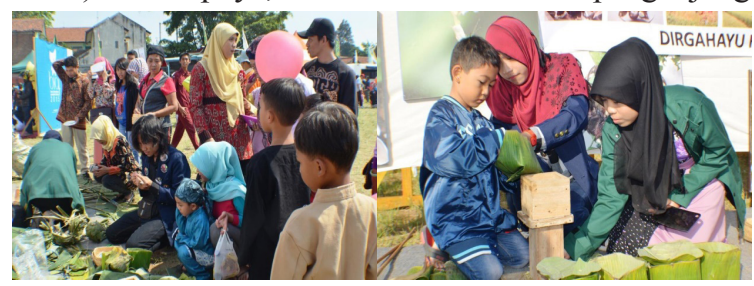

Gambar 5. Suasana Workshop

diberi kesempatan mengikuti workshop dengan dipandu oleh para mahasiswa.

Materi workshop adalah membuat Wawadahan Banda Hajat,yaitu membuat Takir, Konca dan Suji. Kegiatan ini dirancang agar komunikatif, interaktif, dan menyenangkan, antara lain dengan adanya

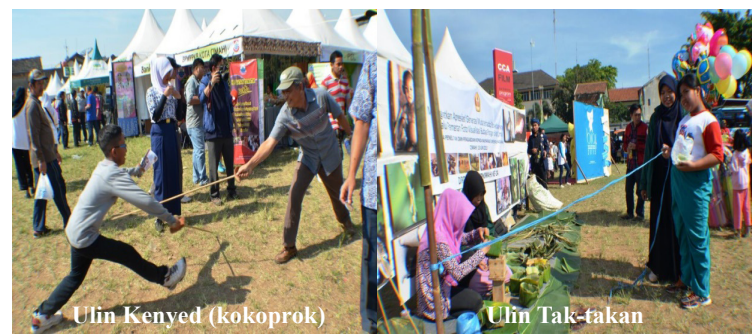

Gambar 6. Permainan

permainan Tak-takan, Ulin Kenyed Kokoprok, foto bersama dengan pengunjung.

Apresiasi pengunjung sangat menggembirakan kami, meskipun tim PKM harus berpanas-panasan. Acara direncanakan berakhir maksimal pukul 14.00 WIB, akan tetapi akibat antusiasme pengunjung baru ditutup sekitar pukul 16.00 WIB. Dalam mengikuti workshop, baik siswa, guru, anggota TNI, PNS, darma wanita, persit, bhayangkari, dan masyarakat umum lainnya, memiliki apresiasi yang tinggi. Workshop sendiri dipandu langsung oleh mahasiswa dan mahasiswi (Mahasiswa DIII Fikom dan Komunitas Dokumentasi Budaya Unpad) dan dibantu oleh staf dari LPPM Unpad.

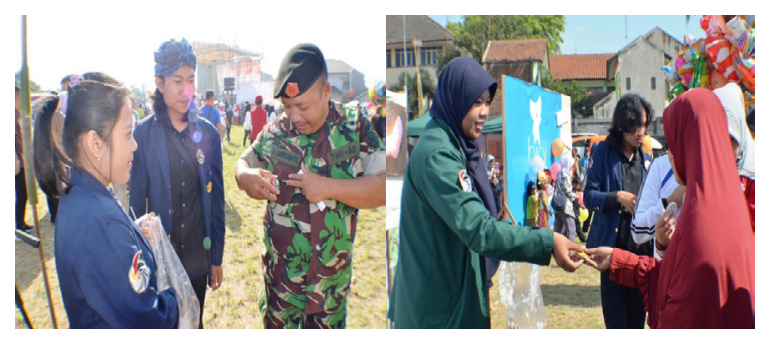

Gambar 7. Pin Unpad Nyaah Ka Jabar 


\section{ULASAN KARYA}

Seefektif apapun dalam berkomunikasi tentu akan mengalami sebuah hambatan. Effendy menyebutkan bahwa dalam berkomunikasi ada yang disebut dengan adanya: gangguan, kepentingan, motivasi, dan prasangka dalam berkomunikasi (Effendy. 2003:45). Sementara pandangan lain menyebutnya tujuh hambatan dalam berkomunikasi yaitu: sosiologis, psikologis, antropologis, semantis, mekanis, ekologis, dan teknis. Merujuk dua pandangan tersebut, maka feedback atau umpan balik dalam kegiatan pameran foto budaya pangan ini harus jelas indikatornya, supaya dalam melakukan monitoring dan evaluasi kegiatan mudah dilakukan.

Komunikasi efektif adalah ketika pesan yang diinginkan sang komunikator dimengerti oleh komunikannya. Indikator pesan tersampaikan dengan baik ketika terjadinya feedback baik langsung maupun tidak langsung. Adapun indikator dimaksud adalah :

A. Indikator umum. Tujuan kegitan pada pameran ini meningkatkan kesadaran masyarakat, khususnya generasi muda/pelajar terhadap pentingnya tanggung jawab bersama dalam pemertahanan ketahan pangan nasional. Semula tim PKM berasumsi bahwa kegiatan pameran kali ini hanya akan dikunjungi oleh orangorang yang betul-betul berminat saja. Apalagi pameran kali ini disaturagakan dengan Hari Jadi Pemkot Cimahi sehingga tim tidak mengetahui siapa tamu undangannya dan juga tidakmengetahui siap potensial pengunjung dan aktual pengunjungnya. Selain itu, lokasi pameran yang jauh dari lokasi permukiman dan diselenggarakan di lapangan terbuka, juga kondisi cuaca pada musim kemarau, sehingga kami sangat pesimis akan banyak pengunjung ke stand LPPM. Pada kenyataannya, dari jumlah pengujung sangat menggembirakan bahkan mereka masih bertahan di stand LPPM sampai pameran ditutup pukul16.00

B. Feedback langsung

a. Apresiasi pengunjung terhadap objek pameran terbukti dengan terjadinya komuinkasi dua arah antara pemandu foto dengan pengunjung. Interaksi ini, berupa tingkat kepenasaran pengunjung tentang objek yang tergambar. Selain itu objekobjek tersebut memberikan kesan nostalgik dan memberikan nilai edukatif.

b. Apresiasi pengunjung terhadap workshop wawadahan banda hajat terbukti dengan terjalinnya komunikasi dua arah antara tim tutor dengan pengunjung peserta workshop. Yang menarik adalah adanya informasi balik (pengunjung memberi pengetahuan yang lain mengenai materi workshop).

c. Apresiasi pengunjung terhadap dekorasi kaulinan urang lembur terbukti dengan bayaknya pengunjung yang bertanya mengenai permainan tersebut dan yang menarik adalah mereka (anak-remaja-dewasa) memainkan permainan tersebut.

d. Selain hal-hal yang disebutkan, terdapat pula kritikkritik langsung berupa komentar, sanggahan, maupun saran. Hal tersebut ditanggapi secara positif oleh panitia internal kami.Antusiasme lainnya, adalah adanya permintaan menyelenggarakan pameran serupa oleh sebagian besar pengunjung.

C. Feedback tidak langsung. Bukti bahwa kegiatan Pameran Foto Visualiasi Budaya Pangan Jawa Barat 2015 mendapat respon yang baik di antaranya adalah adanya peliputan oleh Surat Kabar lokal Cimahi, Hal ini menunjukkan adanya kepedulian masyarakat terhadap nilai edukasi yang terkandung dalam pameran ini, terlepas dari kualitas artistik yang ditampilkan. Nilai-nilai positif tersebut menyarankan adanya ketertarikan kembali terhadap budaya pangan.

Selain peliputan media massa, kami menyediakan layanan kritik dan saran melalui media email, SMS dan jejaring sosial. Sampai saat ini, interaksi ini masih berlanjut dengan beragam konten baik berupa kritik, saran, maupun undangan.

\section{SIMPULAN}

Dalam "Pameran Foto Visualaisasi Budaya Pangan Jawa Barat 2015" dilaksanakan di Lapangan Krida Kota Cimahi hari Sabtu tanggal 13 Juni 2015, dipamerkan 150 foto yang dikelompokkan ke dalam lima tema utama yaitu: pertanian, peternakan, perikanan, pangan alternatif dan alih fungsi lahan serta bab wawadahan banda hajat. Foto yang dipamerkan adalah foto dokumentasi Lembaga Penelitian dan Pengabdian Masyarakat (LPPM) Unpad, kolega, dan panitia, sehingga masyarakat mengetahui hasilhasil penelitian dan PKM yang diselenggarakan oleh akademisi Universitas Padjadjaran.

Berkenaan dengan aktivitas budaya pangan dilakukan pula workshop wawadahan banda hajat dan kaulinan urang lembur.Animo pengunjung untuk kegiatan pameran foto dan workshop mendapat sambutan yang baik dari masyarakat.

Pameran serupa merupakan komunikasi antara perguruan tinggi/Lembaga Penelitian dan Pengabdian kepada Masyarakat dengan masyarakat luas, yang didukung pula oleh Pemerintah Kota Cimahi, Dangiang Sunda Pakidulan (DSP) Ranting Karang Nyungcung Kab. Tasikmalaya. Oleh karena itu, kegiatan kegiatan serupa seharusnya menjadi kegiatan rutin pihak Universitas Padjadjaran.

\section{PENGHARGAAN}

Ucapan terima kasih disampaikan sivitas akademika LPPM Unpad, Divisi KKNM-PPMD Integratif LPPM Unpad, Pemerintah Kota Cimahi, Dangiang Sunda Pakidulan (DSP) Ranting Karang Nyungcung Kab. Tasikmalaya, yang telah mendukukung pelaksanaan Pameran Foto Visualaisasi Budaya Pangan Jawa Barat 2015 dalam rangka meningkatkan apresiasi generasi muda terhadap ketahanan pangan.

\section{DAFTAR PUSTAKA}

Adimihardja, Kusnaka. 2008. Dinamika Budaya Lokal. Bandung: CV Indra Prahasta bersama Pusat Kajian LBPB 
Cms, Samson. 2014. Modul Mata Kuliah Fotografi. Jatinangor: Fakultas Ilmu Komunikasi Universitas Padjadjaran.

Effendi, Onong Uchjana. 1992. Dinamika Komunikasi. Bandung: Rosda Karya

2003. Ilmu, Teori dan Filsafat Komunikasi. Bandung: Citra Aditya Bakti.

Ekadjati, Edi S. 1984. Masyrakat Sunda dan Kebudayaan. Jakarta: Girimukti Pasaka.

Fisher, B. Aubery. 1986. Teori-teori Komunikasi. Bandung: Remaja Rosdakarya.

Kaplan, David dan Manners, Robert. 1999. Teori Budaya. Yogyakarta: Pustaka Pelajar
Koentjaraningrat. 1987. Manusia dan Kebudayaan Indonesia.-: Djambatan

Peursen, CA van. 2005. Strategi Kebudayaan. Yogyakarta: Kanisius

Rakhmat, Jalaluddin. 1999. Psikologi Komunikasi. Bandung. Rosda Karya.

Sukidin, Basrowi. 2002. Metode Penelitian Kualitatif Perspektif Mikro. Surabaya: Insan Cendikia

Sulistyo-Basuki.1992. Teknik dan Jasa Dokumentasi. Jakarta: Gramedia Pustaka Utama.

Sunarjo, Djoenaesih S. 1997. Opini Publik. Yogyakarta: Liberty

Republik Indonesia.Undang-Undang No. 18 Tahun 2012 tentang Pangan. 